\title{
USING DIAMOND CORE BIT TO DETERMINE THE SUITABLE OPERATING PARAMETERS IN DRILLING SOME MARBLE ROCKS
}

\author{
Mostafa M. Elbeblawi ${ }^{1}$, Mohamed A. Sayed ${ }^{2}$, Gamal Y. Boghdadi ${ }^{3}$ and \\ Helal H. Hamd_Allh ${ }^{4}$,*
}

Stuff members in the Mining \& Metal. Eng. Dept., Faculty of Engineering, Assiut University

Received 26 December 2012; accepted 15 January 2013

\begin{abstract}
In this study four marble rocks were drilled by diamond core bit using a fixed laboratory-drilling machine at 400 and $1200 \mathrm{rpm}$, rotational speed, and over a range of weights on bit (WOB) 45, 60, $75,90, \ldots 225 \mathrm{Kg}$. Operating parameters of the drill bit such as WOB, penetration rate (PR), torque (T) and drilling specific energy (SE) were continuously monitored during the drilling trials. The effects of these parameters on the penetration rate were examined, and the effects of formation properties on the drilling rate were examined. Relationships between WOB and both PR, torque T and SE were described and the relationship between PR and SE was determined. Graphs are presented which can be used to predict diamond-drilling performance easy and fast.
\end{abstract}

Kay words: Penetration rate, rotary speed, Weight on bit, Specific energy, Marble rocks

\section{Introduction}

Diamond bit drilling is one of the most widely used and preferable drilling techniques because of its higher rate of penetration and core recovery in the hardest rocks, the ability to drill in any direction with less deviation, and the ability to drill with greater precision in coring and prospecting drilling. [1,2]

Diamond core drilling (Exploration diamond drilling) utilises an annular diamondimpregnated drill bit attached to the end of hollow drill rods to cut a cylindrical core of solid rock. The diamonds used are fine to microfine industrial grade diamonds. They are set within a matrix of varying hardness, from brass to high-grade steel. Matrix hardness, diamond size and dosing can be varied according to the rock which must be cut. Holes within the bit allow water to be delivered to the cutting face. This provides three essential functions; lubrication, cooling, and removal of drill cuttings from the hole. [3]

The penetration rate is generally accepted to be one of the most important parameters in mine planning and cost estimation. An accurate prediction of penetration rate from rock properties and drill operational parameters is of vital importance for the efficient planning of projects. [4]

The drillability of a rock depends on, among other things, the hardness of its constituent minerals and on the grain size and crystal form. Quartz is one of the commonest minerals

\footnotetext{
* Corresponding author.

Mining \& petroleum Eng. Dept., Faculty of Engineering, Al-azhar University, Quena
} 
M. M. Elbeblawi et al, Using Diamond Core Bit To Determine The Suitable Operating Parameters In Drilling Some Marble Rocks, pp. 723 - 745

in rocks. Since quartz is a very hard material, high quartz content (SiO2) makes the rock very hard to drill and causes heavy wear, particularly on the drill bits, we say that the rock is abrasive. Conversely, a rock with a high content of calcite is easy to drill and causes little wear on the drill bits. [5, 6]

In an engineering study of rotary drilling, the factors which affect rate of penetration (PR) are mostly grouped

into formation parameters and rig/bit related parameters. These factors include personnel efficiency, formation characteristics (strength, hardness, abrasiveness), mechanical factors (weight on bit, bit type, rotary speed), hydraulic factors as well as drilling fluid properties. $[7,8]$

Recording drilling parameters is a useful and economical technique for acquiring geomechanical information of rock mass parameters The specific energy (SE) can be defined as of the energy necessary to drill a determined volume of rock (MPa).[8,9,10]

All drilling trials were carried out at two main rotary speeds low speed (400 rpm) and high speed (1200 rpm).

Lengths of core produced from the testes are measured and time taken for the drilling is monitored so the penetration rate calculated is equal length of core /time. Note, the average penetration rates were estimated from the drilling trials at low and high speed for one load and the same load.

The aim of this paper is to:

1- Determine the relationships between some operating factors in diamond core drilling such as WOB, RPM, SE and Torque with penetration rate in some marble rocks.

2- Determine the Suitable operating parameters, which give the best value of (PR) and low value of drilling specific energy.

\section{Egyptian marble and its occurrences}

Marble is a crystalline, compact variety of metamorphosed limestone, consisting primarily of calcite $(\mathrm{CaCO} 3)$, dolomite $(\mathrm{CaMg} \mathrm{CO} 3)$ or a combination of both minerals. Pure calcite is white, but mineral impurities add color in variegated patterns.

Commercially the term marble is extended to include any rock composed of calcium carbonate that requires polish, including ordinary limestone. The term is further extended to include stones such as alabaster, serpentine and other soft rocks. Marble is a durable stone in dry atmosphere only when protected from rain. The surface of marble crumbles readily when exposed to moist or acidic environment. Purest form of marble is statuary marble, which is white with visible crystalline structure. The distinctive luster of

Journal of Engineering Sciences, Assiut University, Faculty of Engineering, Vol. 41, No. 2, March, 2013, E-mail address: jes@aun.edu.eg 
M. M. Elbeblawi et al, Using Diamond Core Bit To Determine The Suitable Operating Parameters In Drilling Some Marble Rocks, pp. 723 - 745

statuary marble is caused by the reflection of penetrated light from the surfaces of inner crystals. [11]

Marble stratigraphy; marble is found in Middle Eocene nummulitic limestone formations. Lithology: Marble exhibits different structures: botryoidally structure, banding, cockade structure, vugs and cavities. [12]

In terms of geological definition, it is a metamorphosed limestone produced by recrystallisation under condition of thermal and also regional metamorphism. In commercial parlance almost any rocks consisting of calcium and/or magnesium carbonate which can take polish easily more, especially unmetamorphosed limestone are termed as marble. [13]

\section{Petrography of the study marble rocks}

The different types of marble rocks are collected from two locations, two types white and black marble from Wadi El Miah marble quarry and another two types from Elshikh Fadl marble quarry.

\subsection{The co-ordinates of the locations are:}

\subsubsection{Wadi el-miah}

Latitude $\quad 25^{\circ} 05^{\prime} 56.50^{\prime \prime} \mathrm{N}$.

Longitude $\quad 33^{\circ} 47^{\prime} 49.90^{\prime \prime}$ E.

\subsubsection{El sheikh fadl}

Latitude $\quad 28^{\circ} 20^{\prime} \quad 49.44^{\prime \prime} \quad \mathrm{N}$.

Longitude $\quad 31^{\circ} 48^{\prime} 18.99^{\prime \prime}$ E.

\subsection{Wadi el-miah marble}

\subsubsection{Black marble}

The hand specimen is usually black and fine grained and characterized by white veins showing foliation and fine to medium grain type composed mainly of calcite and traces of quartz fig (1), (2).

\subsubsection{White marble}

The hand specimen of marble is white in color and intersected by grey veins and massive to fine grain in texture. Under the microscope it is mainly of calcite and some nacre of quartz. Calcite is subhedral crystal and quartz is anhedral fig (3), (4).

Journal of Engineering Sciences, Assiut University, Faculty of Engineering, Vol. 41, No. 2, March, 2013, E-mail address: jes@aun.edu.eg 
M. M. Elbeblawi et al, Using Diamond Core Bit To Determine The Suitable Operating Parameters In Drilling Some Marble Rocks, pp. 723 - 745

\subsection{El shikh_fadl marble}

\subsubsection{Sunny marble}

The hand specimen of marble white to brownish in color, fine grained in size and containing some lenses of quartz with some fractures. Under the microscope composed it is mainly of calcite and some traces from quartz and iron oxides as accessories. This rock containing some fossils types fig (5), (6).

\subsubsection{Yellow marble}

The hand specimen marble white to brownish in color and fine grain in size. Composed mainly of calcite, and some quartz traces and iron oxides as accessories fig (7), (8).

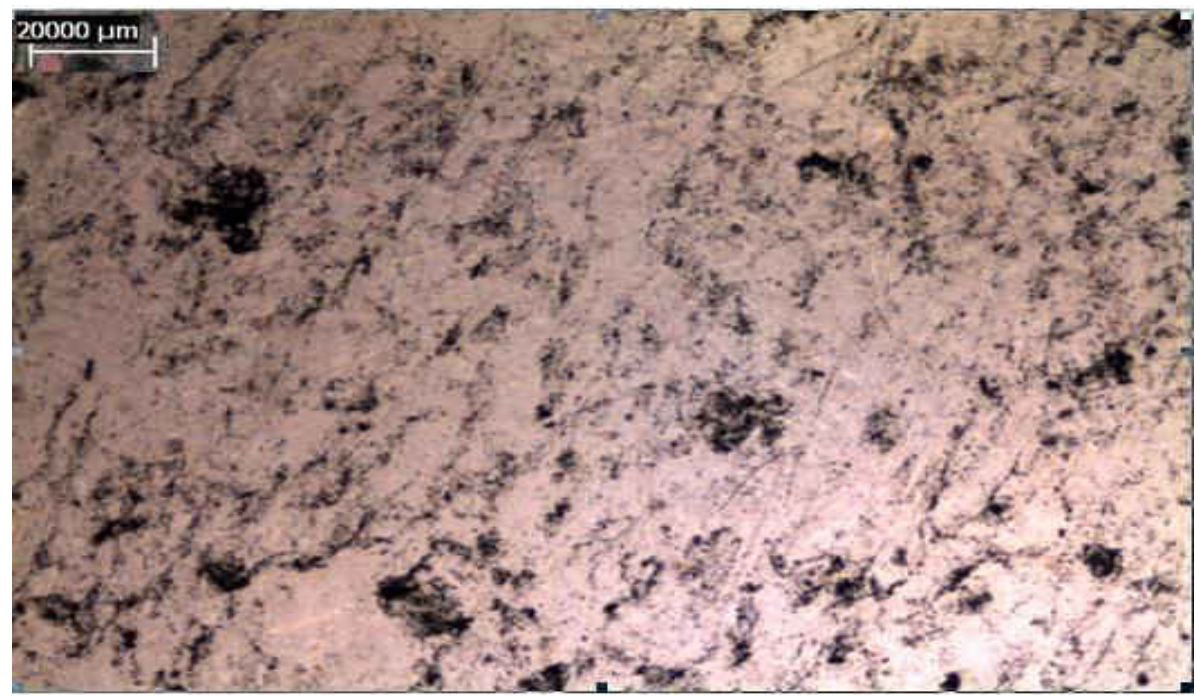

Fig. 1. Photo micrograph in Black marble showing the calcite

Journal of Engineering Sciences, Assiut University, Faculty of Engineering, Vol. 41, No. 2, March, 2013, E-mail address: jes@aun.edu.eg 
M. M. Elbeblawi et al, Using Diamond Core Bit To Determine The Suitable Operating Parameters In Drilling Some Marble Rocks, pp. 723 - 745

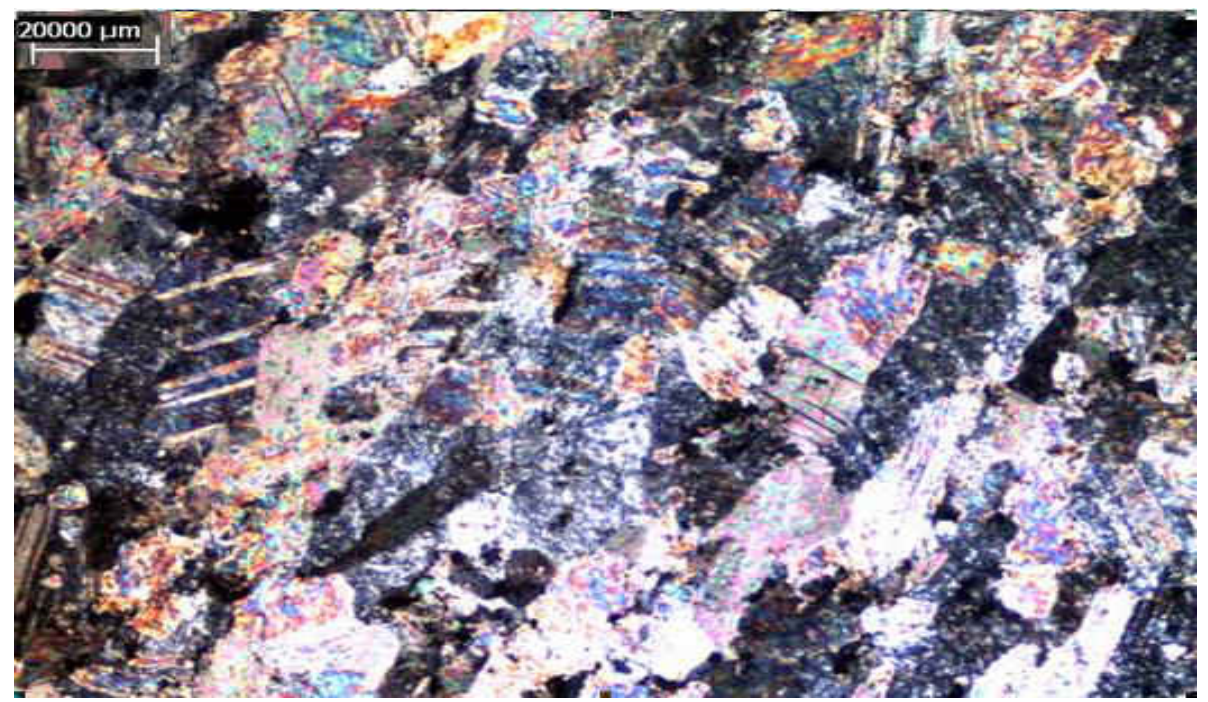

Fig. 2. Photo micrograph in Black marble showing the Quartz

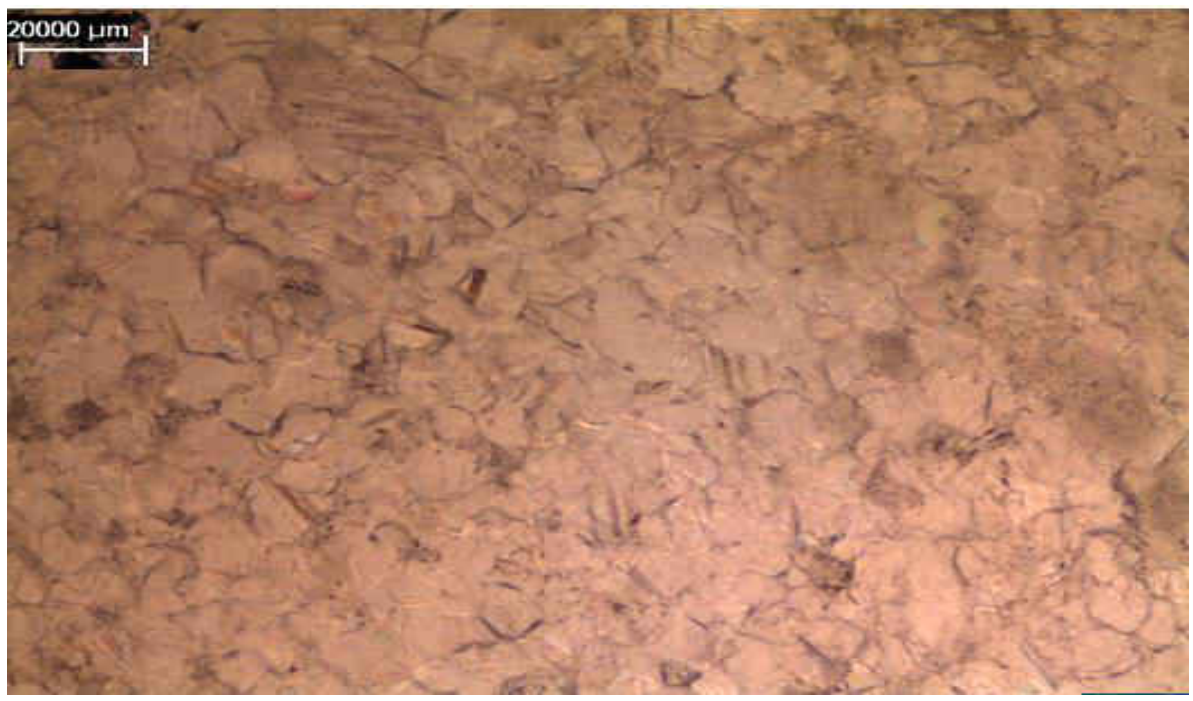

Fig. 3. Photo micrograph in White marble showing the Calcite

Journal of Engineering Sciences, Assiut University, Faculty of Engineering, Vol. 41, No. 2, March, 2013, E-mail address: jes@aun.edu.eg 
M. M. Elbeblawi et al, Using Diamond Core Bit To Determine The Suitable Operating Parameters In Drilling Some Marble Rocks, pp. 723 - 745

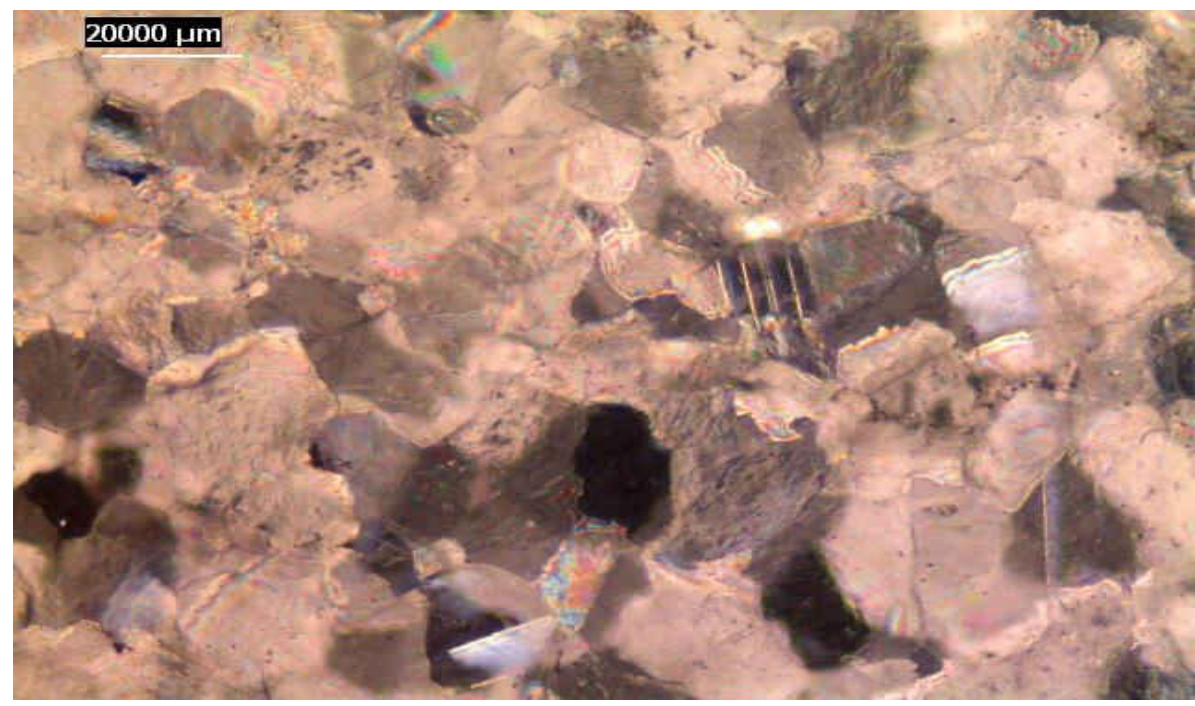

Fig. 4. photo micrograph in White marble showing the Quartz

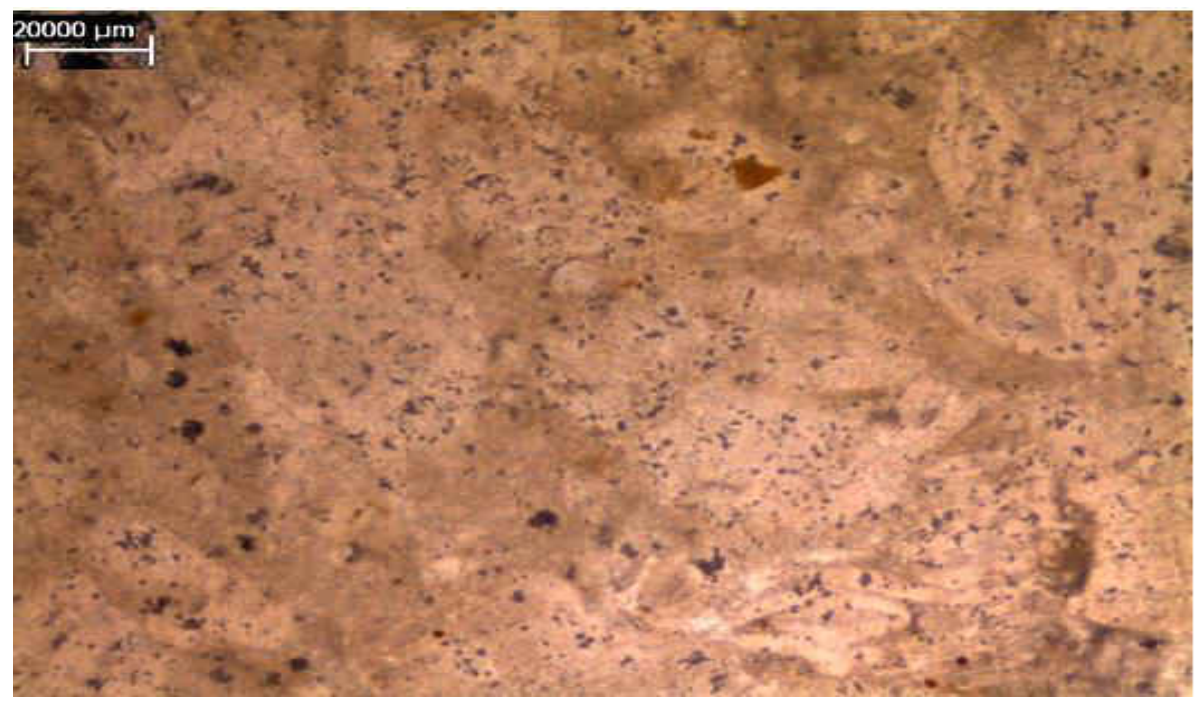

Fig. 5. Photo micrograph in Sunny marble showing the Quartz

Journal of Engineering Sciences, Assiut University, Faculty of Engineering, Vol. 41, No. 2, March, 2013, E-mail address: jes@aun.edu.eg 
M. M. Elbeblawi et al, Using Diamond Core Bit To Determine The Suitable Operating Parameters In Drilling Some Marble Rocks, pp. 723 - 745

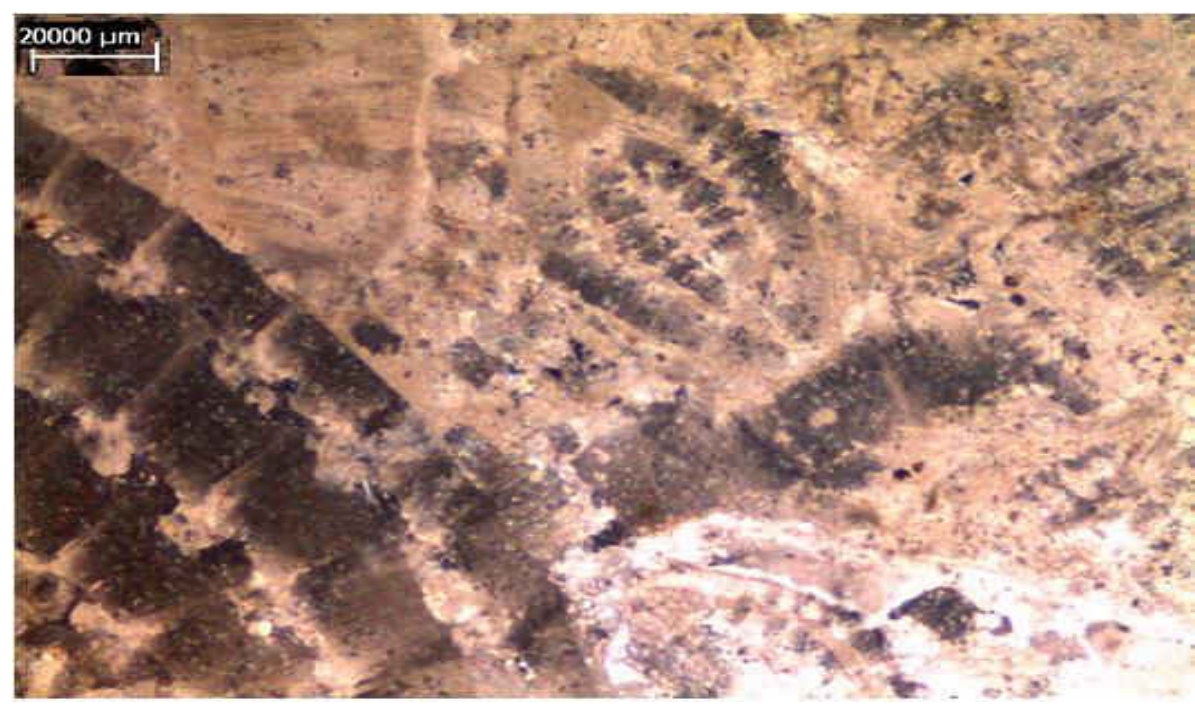

Fig. 6. Photo micrograph in Sunny marble showing the fossils.

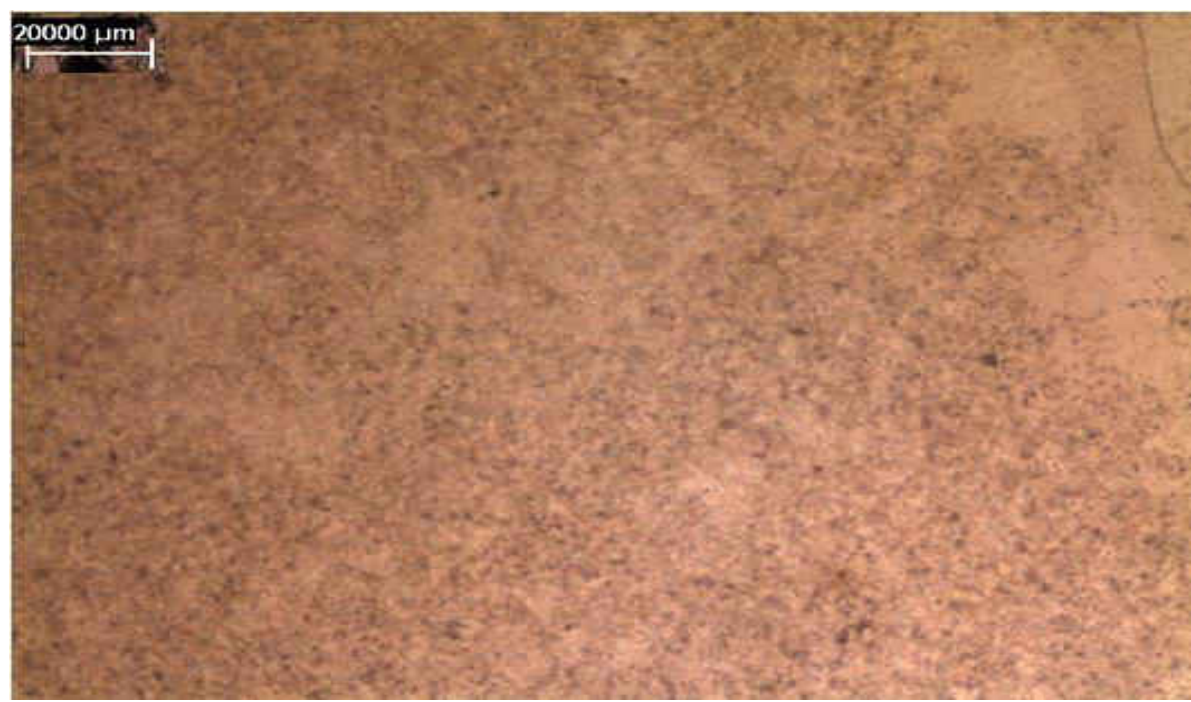

Fig. 7. Photo micrograph in Yellow marble showing the calcite

Journal of Engineering Sciences, Assiut University, Faculty of Engineering, Vol. 41, No. 2, March, 2013,E-mail address: jes@aun.edu.eg 
M. M. Elbeblawi et al, Using Diamond Core Bit To Determine The Suitable Operating Parameters In Drilling Some Marble Rocks, pp. 723 - 745

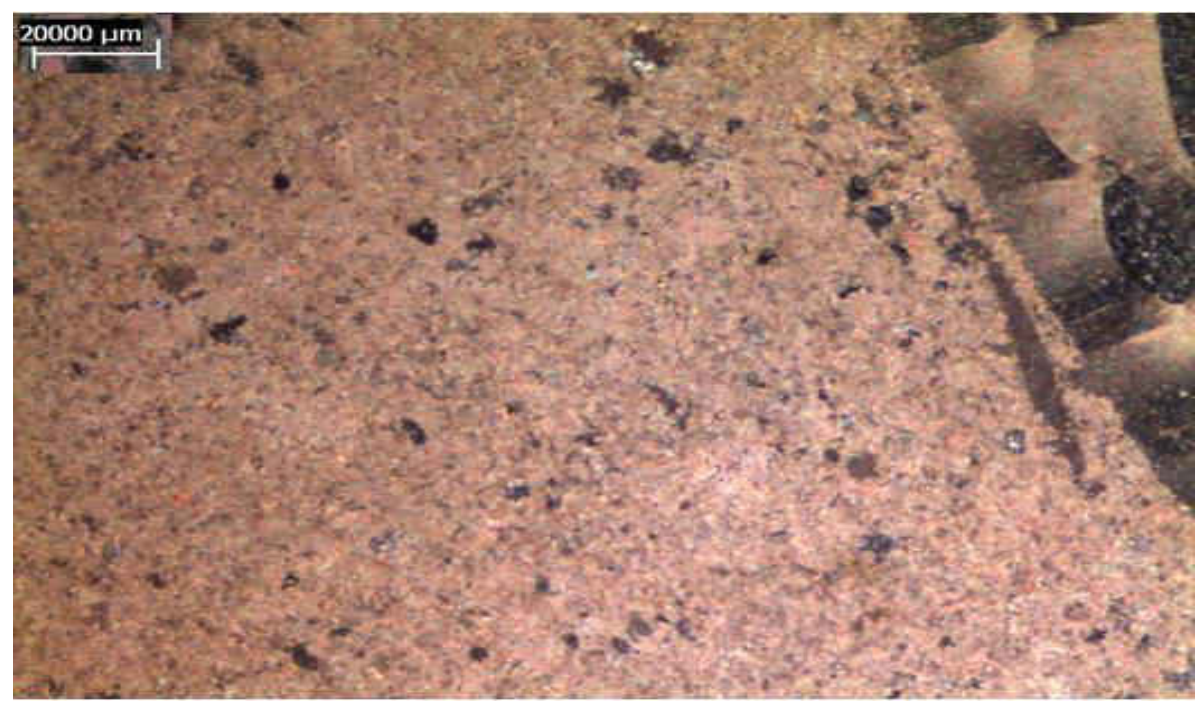

Fig. 8. Photo micrograph in Yellow marble showing the quartz.

\section{Properties of the tested rocks}

In this study physical and mechanical properties such as density, porosity, compressive strength, tensile strength and coefficient of friction with its standard deviation, are given in Table (1).

\section{Table 1}

Average physical and mechanical properties of the tested rocks.

\begin{tabular}{cccccc}
\hline Marble & Density & Porosity \% & Compressive & Tensile & Coeffi.Of \\
Rock & gr/cm3 & & strength & strength & friction \\
type & & & & & \\
\hline Black & $2.99 \pm 0.006$ & $1.01 \pm 0.140$ & $585.98 \pm 59.7$ & $137.21 \pm 3.86$ & 0.65 \\
White & $3.10 \pm 0.007$ & $0.66 \pm 0.099$ & $623.02 \pm 31.62$ & $170.02 \pm 7.60$ & 0.70 \\
Sunny & $2.87 \pm 0.007$ & $2.51 \pm 0.170$ & $439.15 \pm 60.12$ & $105.47 \pm 3.19$ & 0.99 \\
Yellow & $2.56 \pm 0.006$ & $2.32 \pm 0.120$ & $439.15 \pm 60.12$ & $111.46 \pm 13.74$ & 0.81 \\
\hline \hline
\end{tabular}

Journal of Engineering Sciences, Assiut University, Faculty of Engineering, Vol. 41, No. 2, March, 2013, E-mail address: jes@aun.edu.eg 
M. M. Elbeblawi et al, Using Diamond Core Bit To Determine The Suitable Operating Parameters In Drilling Some Marble Rocks, pp. 723 - 745

\section{Experimental work}

In the current research four types of the marble rocks from different places in Aswan (Eastern desert) and

El-Minya in Egypt were tested. Rocks prepared as blocks of dimensions( $20 \mathrm{~cm} \times 15 \mathrm{~cm} \times 15 \mathrm{~cm}$ ), Blocks tested in the laboratory by diamond drilling machine the inside diameter of the used bit $38 \mathrm{~mm}$ with $40 \mathrm{~mm}$ outer diameter. Applied load, actual speed, length of borehole (length of core) and time of drilling are recorded. All drilling trails were carried out at low speed equals $400 \mathrm{rpm}$ and high speed equals $1200 \mathrm{rpm}$. Rotary speed in the tests measured by laser speedometer. Water used as a drilling fluid for cooling the bit and remove the cuttings.

The weight on bit is applied by using loads which are suspended by a movable wheel by a wire rope. The wheel is fixed into the machine gear axis. Hence the load is transferred into the bit. This transfered load is checked up and measured using proving ring.

\section{Results and discussion}

The following are the relationships between (WOB via PR), (WOB via Torque), (WOB via $\mathrm{SE})$ and (PR via SE) at low and high speed.

\subsection{Relations between $W O B$ and $P R$ at low and high speed}

Penetration rate at low and high speed for different WOB in the tested rocks are shown in the table (2)

Table 2

Results of PR and SE at low and high speeds for tested rocks at different WOB

\begin{tabular}{|c|c|c|c|c|c|c|c|c|c|c|c|c|c|c|c|c|}
\hline \multirow{3}{*}{ WOB } & \multicolumn{4}{|c|}{ Black marble } & \multicolumn{4}{|c|}{ White marble } & \multicolumn{4}{|c|}{ Sunny marble } & \multicolumn{4}{|c|}{ Yellow marble } \\
\hline & \multicolumn{2}{|c|}{ Low speed } & \multicolumn{2}{|c|}{ High speed } & \multicolumn{2}{|c|}{ Low speed } & \multicolumn{2}{|c|}{ High speed } & \multicolumn{2}{|c|}{ Low speed } & \multicolumn{2}{|c|}{ High speed } & \multicolumn{2}{|c|}{ Low speed } & \multicolumn{2}{|c|}{ High speed } \\
\hline & $\begin{array}{r}\text { PR, } \\
\text { nm/sec }\end{array}$ & $\begin{array}{c}\text { S.E, } \\
\text { Mpa }\end{array}$ & $\begin{array}{r}\text { PR, } \\
\mathrm{nm} / \mathrm{sec}\end{array}$ & $\begin{array}{c}\text { S.E, } \\
\text { Mpa }\end{array}$ & $\begin{array}{r}\text { PR, } \\
\mathrm{nm} / \mathrm{sec}\end{array}$ & $\begin{array}{c}\text { S.E, } \\
\text { Mpa }\end{array}$ & $\begin{array}{r}\text { PR, } \\
\mathrm{nm} / \mathrm{sec}\end{array}$ & $\begin{array}{c}\text { S.E, } \\
\text { Mpa }\end{array}$ & $\begin{array}{r}\text { PR, } \\
\mathrm{mm} / \mathrm{sec}\end{array}$ & $\begin{array}{c}\text { S.E, } \\
\text { Mpa }\end{array}$ & $\begin{array}{r}\text { PR, } \\
\mathrm{mm} / \mathrm{sec}\end{array}$ & $\begin{array}{c}\text { S.E, } \\
\text { Mpa }\end{array}$ & $\begin{array}{r}\text { PR, } \\
\mathrm{mm} / \mathrm{sec}\end{array}$ & $\begin{array}{l}\text { S.E, } \\
\text { Mpa }\end{array}$ & $\begin{array}{r}\text { PR, } \\
\mathrm{lm} / \mathrm{sec}\end{array}$ & $\begin{array}{l}\text { S.E, } \\
\text { Mpa }\end{array}$ \\
\hline 45 & - & - & - & - & & - & 0.43 & 1219 & - & - & - & - & - & & 0.17 & 3566 \\
\hline 60 & - & - & - & - & & - & 0.47 & 1488 & - & - & 0.45 & 2192 & - & & 0.29 & 2787 \\
\hline 75 & - & - & 0.67 & 1212 & - & - & 0.56 & 1561 & - & - & 0.46 & 2681 & 0.17 & 1977 & 0.51 & 1981 \\
\hline 90 & - & - & 0.68 & 1433 & 0.11 & 3172 & 1.07 & 980 & 0.19 & 7789 & 0.71 & 2084 & 0.19 & 2123 & 0.99 & 1225 \\
\hline 105 & - & - & 0.80 & 1421 & 0.15 & 2714 & 1.37 & 893 & 0.21 & 8222 & 0.88 & 1962 & 0.24 & 1961 & 1.30 & 1088 \\
\hline 120 & 0.21 & 1946 & 0.89 & 1460 & 0.23 & 2023 & 1.85 & 756 & 0.21 & 9397 & 0.94 & 2099 & 0.27 & 1992 & 1.41 & 1146 \\
\hline 135 & 0.24 & 1915 & 1.01 & 1447 & - & - & - & - & 0.22 & 10091 & 1.04 & 2134 & 0.27 & 2241 & 1.35 & 1347 \\
\hline 150 & 0.28 & 1824 & 1.20 & 1353 & 0.39 & 1491 & - & - & 0.26 & 9487 & 0.71 & 3474 & 0.32 & 2101 & 1.20 & 1684 \\
\hline 165 & 0.3 & 1873 & 1.34 & 1333 & 0.47 & 1361 & - & - & 0.27 & 10049 & - & - & 0.35 & 2113 & - & - \\
\hline 180 & 0.31 & 1977 & 1.55 & 1257 & 0.57 & 1224 & - & - & 0.28 & 10571 & - & - & 0.39 & 2068 & - & - \\
\hline 195 & 0.33 & 2012 & - & - & 0.88 & 859 & - & - & 0.32 & 10021 & - & - & 0.44 & 1986 & - & - \\
\hline 210 & 0.34 & 2103 & - & - & 1.59 & 512 & - & - & 0.34 & 10157 & - & - & 0.48 & 1961 & - & - \\
\hline 225 & - & - & - & - & - & - & - & - & 0.38 & 9737 & - & - & - & - & - & - \\
\hline
\end{tabular}

Journal of Engineering Sciences, Assiut University, Faculty of Engineering, Vol. 41, No. 2, March, 2013, E-mail address:jes@aun.edu.eg 
M. M. Elbeblawi et al, Using Diamond Core Bit To Determine The Suitable Operating Parameters In Drilling Some Marble Rocks, pp. 723 - 745

Relation between WOB and penetration rate PR in Marble rocks at two rotary speeds $(400 \mathrm{rpm})$ and (1200 rpm) were represented by curves in figures (9), (10), (11), and (12). The trend line for the results is that increasing WOB produces an increase in PR up to a maximum point. However, from the experimental data in table (2), a further increase in WOB causes constant or little increase in PR. The effect of rotational speed on PR of the bit is clear in the curves and data in table (2), increasing rotary speed produced an increase in the PR. At WOB $210 \mathrm{~kg}$ PR in (Black marble) was about 1.6 times that at min. $120 \mathrm{~kg}$. There is also an increase in PR in rocks (White marble), (Sunny marble) and (Yellow marble) with increased WOB. PR in rocks (White marble), (Sunny marble) and (Yellow marble) at WOB 210,225 and $210 \mathrm{~kg}$ was about 14.5, 2 and 2.8 times that at 90, 90 and 75 $\mathrm{kg}$ respectively in the low speed. In high speed PR in rock (Black marble) at WOB $180 \mathrm{~kg}$ was about 2.3 times that at $75 \mathrm{~kg}$. PR in rocks (White marble), (Sunny marble) and (Yellow marble) at WOB 120,150 and $150 \mathrm{~kg}$ was about 4.3, 1.6 and 7 times that at 45, 60 and $45 \mathrm{~kg}$ respectively.

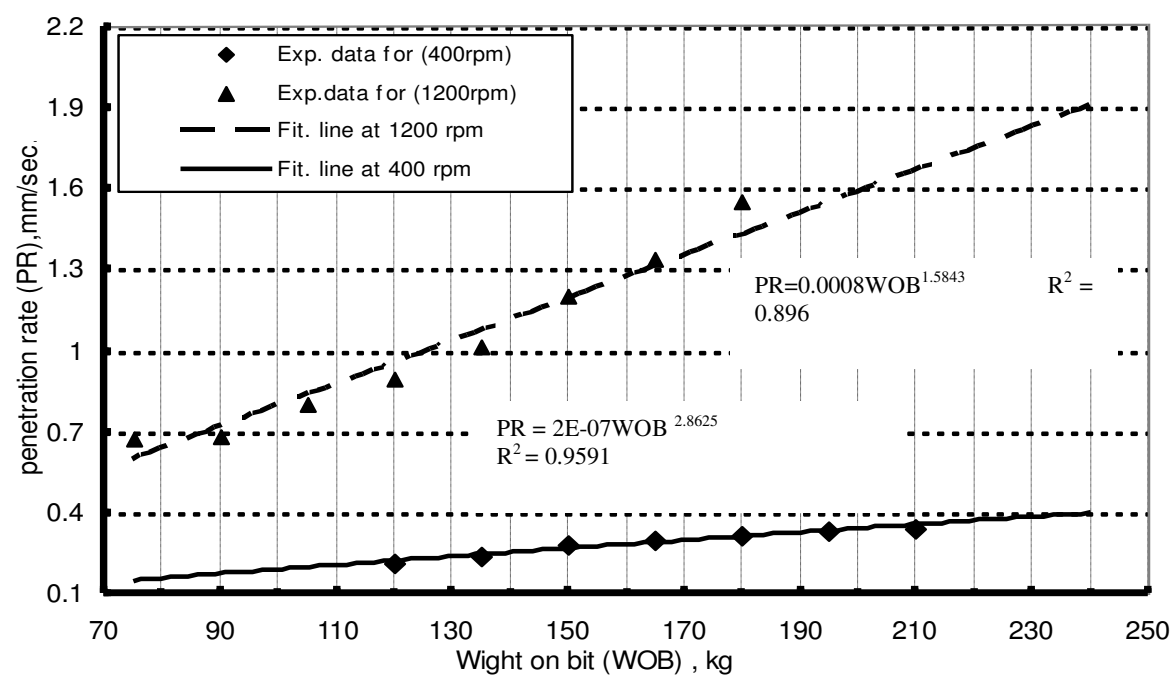

Fig. 9. Relation between $\mathrm{WOB}$ and $\mathrm{PR}$ at $400 \mathrm{rpm}$ and $1200 \mathrm{rpm}$ for Black Marble

Journal of Engineering Sciences, Assiut University, Faculty of Engineering, Vol. 41, No. 2, March, 2013, E-mail address: jes@aun.edu.eg 
M. M. Elbeblawi et al, Using Diamond Core Bit To Determine The Suitable Operating Parameters In Drilling Some Marble Rocks, pp. 723 - 745

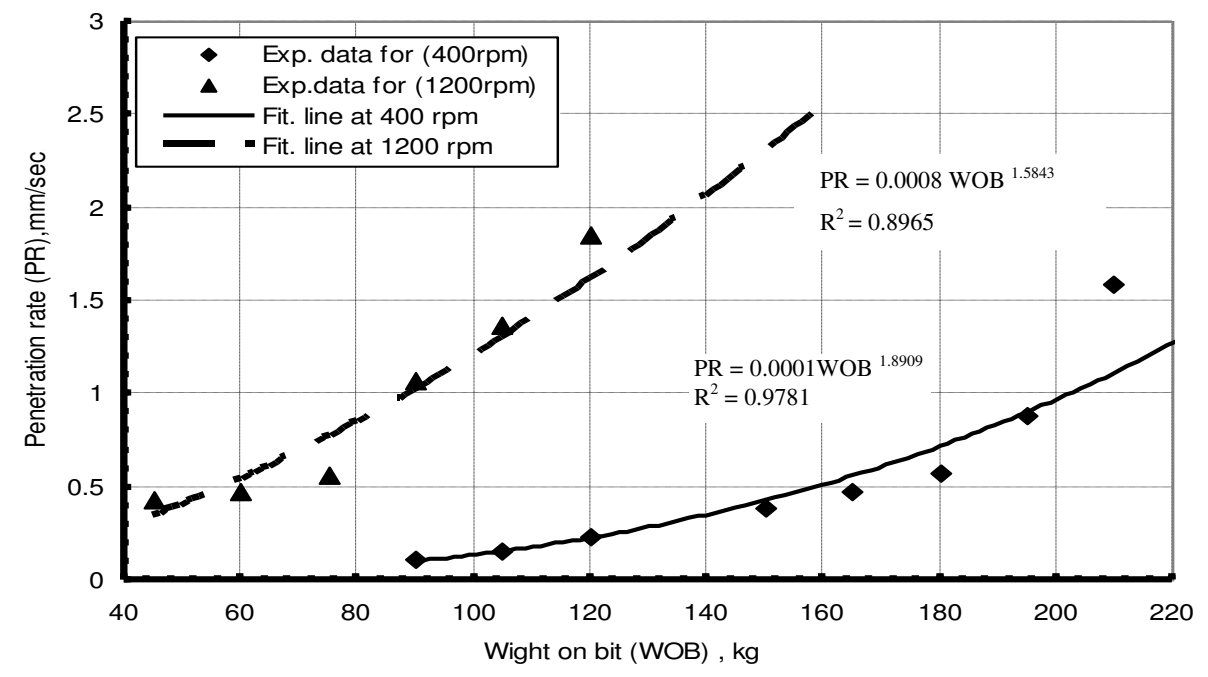

Fig. 10. Relation between $W O B$ and $P R$ at $400 \mathrm{rpm}$ and $1200 \mathrm{rpm}$ for White Marble

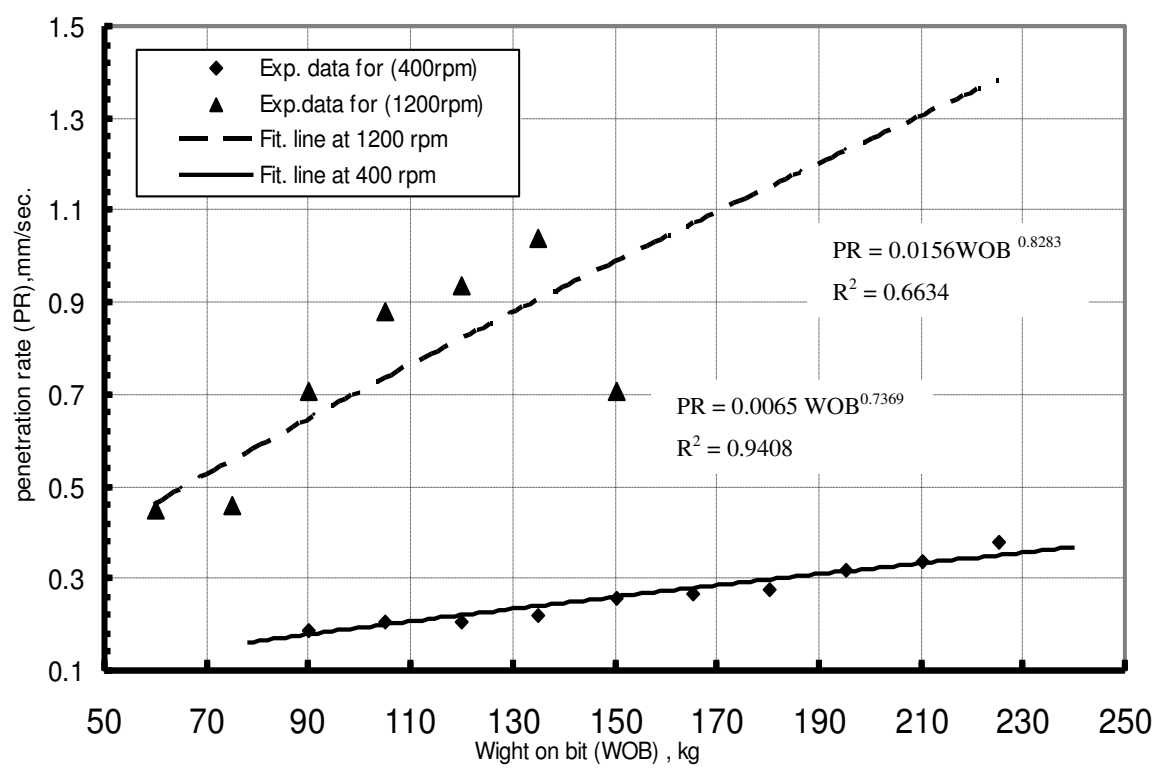

Fig. 11. Relation between $W O B$ and $P R$ at $400 \mathrm{rpm}$ and $1200 \mathrm{rpm}$ for Sunny Marble

Journal of Engineering Sciences, Assiut University, Faculty of Engineering, Vol. 41, No. 2, March, 2013, E-mail address: jes@aun.edu.eg 
M. M. Elbeblawi et al, Using Diamond Core Bit To Determine The Suitable Operating Parameters In Drilling Some Marble Rocks, pp. $723-745$

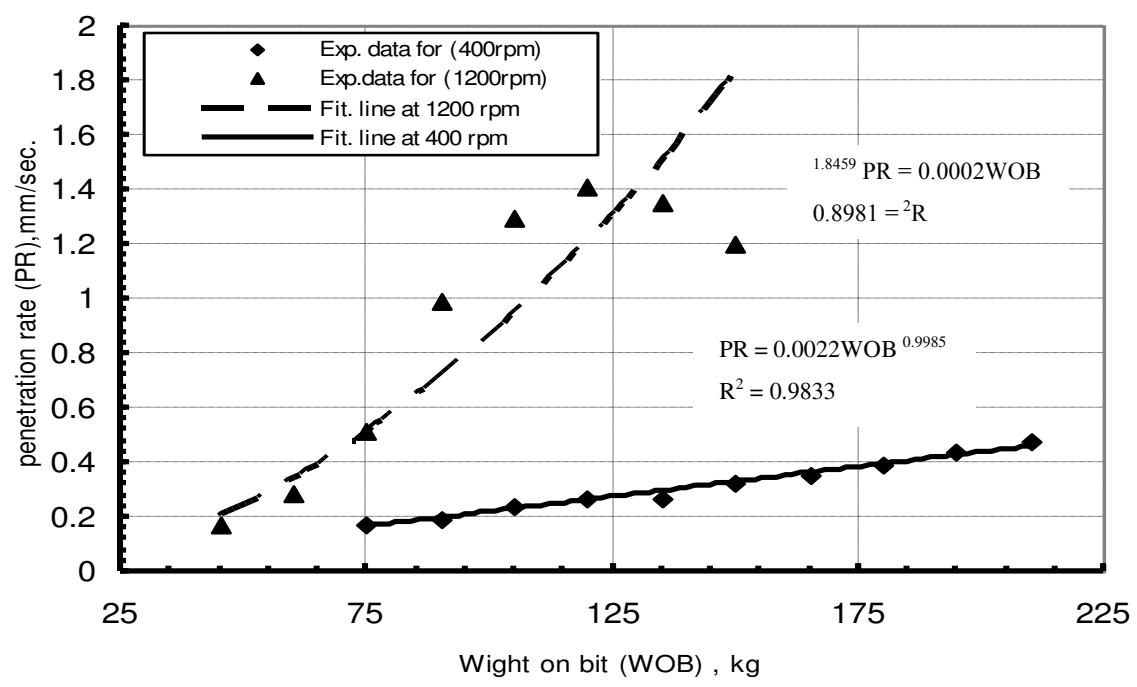

Fig. 12. Relation between WOB and PR at $400 \mathrm{rpm}$ and $1200 \mathrm{rpm}$ for Yellow Marble

\subsection{Relations between wob and torque}

Torque is defined as the force required to turn the drill rod, which leads to the bit rotation against the resistance to the cutting and friction forces. [14] Rotary torque is an indicator of what is happening at the drill bit. Relationship between Torque (T) and weight on bit (WOB) is linear. The torque is found to be dependent on the weight on bit to the power of 1.1 according to field measurements. [15]

$$
\mathbf{T}=\frac{2}{3} \boldsymbol{\mu} \mathbf{F}_{\mathbf{v}} \frac{r_{0}^{3}-r_{i}^{3}}{r_{0}^{2}-r_{i}^{2}}
$$

$\mathrm{T}=$ resisting torque, $\mathrm{N} \cdot \mathrm{M}$

$$
\mathrm{FV}=\text { applied thrust, } \mathrm{KG}
$$

$\mu=$ Coefficient of

friction

$$
\mathrm{r}_{\mathrm{o}}=\text { outside radius }, \mathrm{m} \quad \mathrm{r}_{\mathrm{i}}=\text { inside radius }, \mathrm{m}
$$

Table (3) gives the values of torque for the tested rocks which are calculated at different WOB. Relations between WOB and T are illustrated in the figure (13) as an example; there is a linear relation between WOB and $\mathrm{T}$.

Torque value increases with the increase in WOB in the four rocks.

Journal of Engineering Sciences, Assiut University, Faculty of Engineering, Vol. 41, No. 2, March, 2013,E-mail address: jes@aun.edu.eg 
M. M. Elbeblawi et al, Using Diamond Core Bit To Determine The Suitable Operating Parameters In Drilling Some Marble Rocks, pp. 723 - 745

\section{Table (3)}

Values of torque for the tested rocks at different WOB

\begin{tabular}{|c|c|c|c|c|}
\hline WOB & Black marble & White marble & Sunny marble & $\begin{array}{c}\text { Yellow } \\
\text { marble }\end{array}$ \\
\hline & Torque, N.m & Torque, N.m & Torque, N.m & Torque, N.m \\
\hline 45 & - & 6.35 & - & 7.34 \\
\hline 60 & - & 8.46 & 35.88 & 9.78 \\
\hline 75 & 9.83 & 10.58 & 44.85 & 12.23 \\
\hline 90 & 11.79 & 12.69 & 53.82 & 14.67 \\
\hline 105 & 13.76 & 14.81 & 62.79 & 17.12 \\
\hline 120 & 15.72 & 16.92 & 71.76 & 19.56 \\
\hline 135 & 17.69 & - & 80.73 & 22.01 \\
\hline 150 & 19.65 & 21.15 & 89.70 & 24.45 \\
\hline 165 & 21.62 & 23.27 & 98.67 & 26.90 \\
\hline 180 & 23.58 & 25.38 & 107.64 & 29.34 \\
\hline 195 & 25.58 & 27.50 & 116.61 & 31.79 \\
\hline 210 & 27.51 & 29.61 & 125.58 & 34.23 \\
\hline 225 & - & - & 134.55 & - \\
\hline
\end{tabular}

Journal of Engineering Sciences, Assiut University, Faculty of Engineering, Vol. 41, No. 2, March, 2013,E-mail address: jes@aun.edu.eg 
M. M. Elbeblawi et al, Using Diamond Core Bit To Determine The Suitable Operating Parameters In Drilling Some Marble Rocks, pp. $723-745$

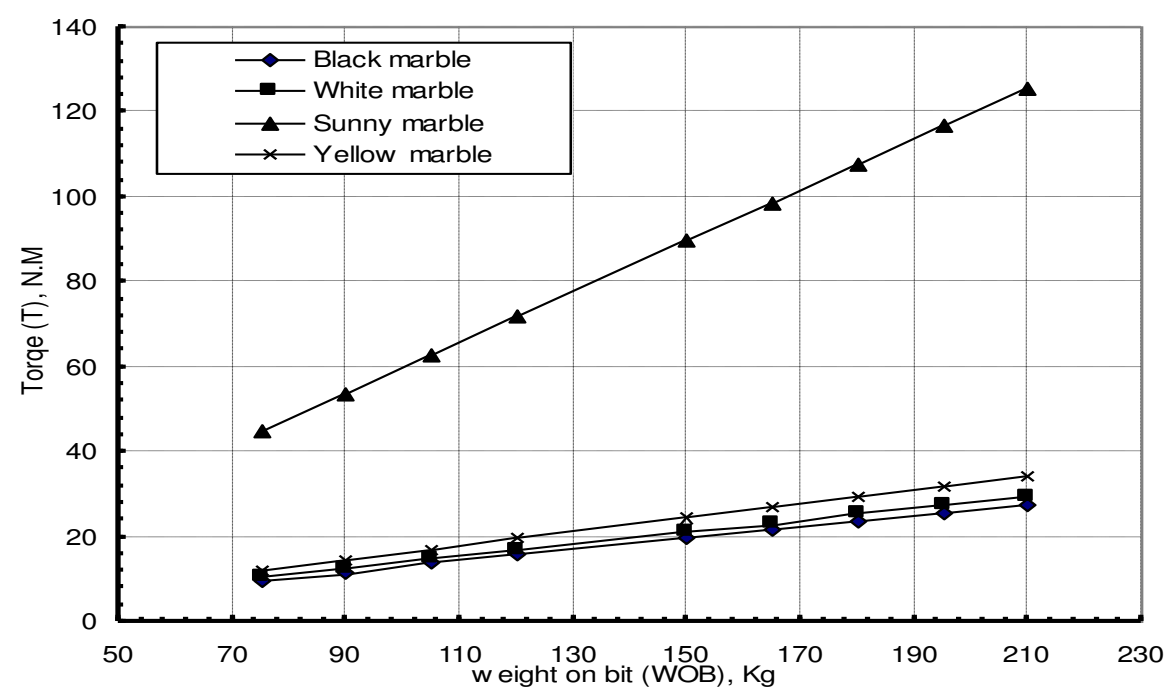

Fig. 13. Relation between weight on bit and torque in marble rocks

\subsection{Relations between WOB and SE at low and high speed}

The specific energy (SE) is defined as the energy required for excavating unit volume of rock .It is a useful parameter that may also be taken as an index of the mechanical efficiency of a rock-working process .Specific energy is directly linked to the cost used in drill the hole, so the specific energy is the clear indication on the drilling performance in the rocks drilled in this study. By definition it can be defined as input energy to the output PR. The SE equation can be expressed in terms of drilling parameters can a follows $[2,16$, 17]

$$
\mathrm{SE}=2 \pi * \mathrm{NT} / \mathrm{A} * \mathrm{PR}
$$

$\mathrm{SE}=$ specific energy; MPa.

$\mathrm{N}=$ rotary speed, rpm .

$\mathrm{T}=$ resistance torque, $\mathrm{Nm}$.

$\mathrm{A}=$ area of the bit, $\mathrm{mm}^{2}$.

$\mathrm{PR}=$ penetration rate. $\mathrm{M} / \mathrm{hr}$.

Specific energy was calculated from the above equation for all testes in high and low speeds, and the values are given in table (2). A curve fitting was made for experimental data. Relations between WOB and SE with correlation coefficients are given in figs (14), (15), (16) and (17). In the figures the trend line behavior varies according to rock type and rotary speed. The best values of SE which give best values of PR were 512 and $1961 \mathrm{Mpa}$ at WOB $210 \mathrm{Kg}$ in rocks white and yellow marble at $400 \mathrm{rpm}$ respectively.

Journal of Engineering Sciences, Assiut University, Faculty of Engineering, Vol. 41, No. 2, March, 2013,E-mail address: jes@aun.edu.eg 
M. M. Elbeblawi et al, Using Diamond Core Bit To Determine The Suitable Operating Parameters In Drilling Some Marble Rocks, pp. 723 - 745

The best values of SE which give reasonable values of PR were $1824 \mathrm{MPa}$ and $7789 \mathrm{MPa}$ at WOB 150 and $90 \mathrm{Kg}$ in black and Sunny marble at $400 \mathrm{rpm}$. The best values of SE which give best values of PR were 1257 and $756 \mathrm{Mpa}$ at WOB 180 and $120 \mathrm{Kg}$ in rocks black and white marble at $1200 \mathrm{rpm}$ respectively. The best values of SE which give reasonable values of PR were $1962 \mathrm{MPa}$ and $1088 \mathrm{Mpa}$ at WOB $105 \mathrm{Kg}$ in sunny and yellow marble at $1200 \mathrm{rpm}$ respectively.

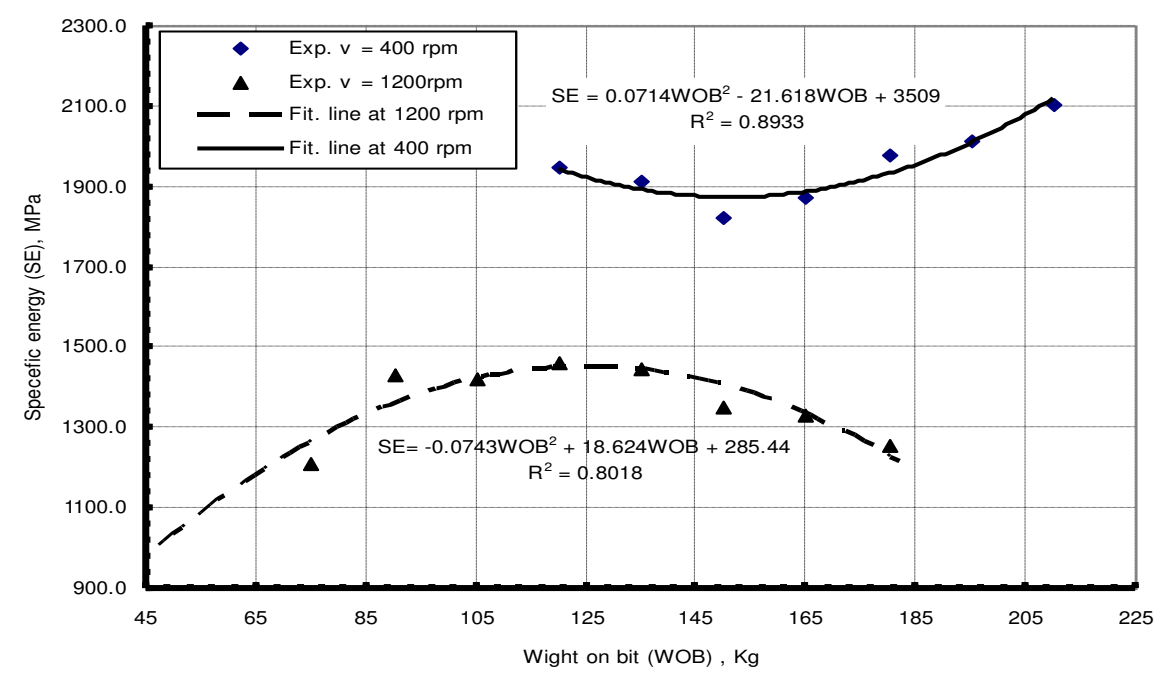

Fig. 14. Relation between (WOB) and (SE) at $400 \mathrm{rpm}$ and $1200 \mathrm{rpm}$ for Black Marble rock.

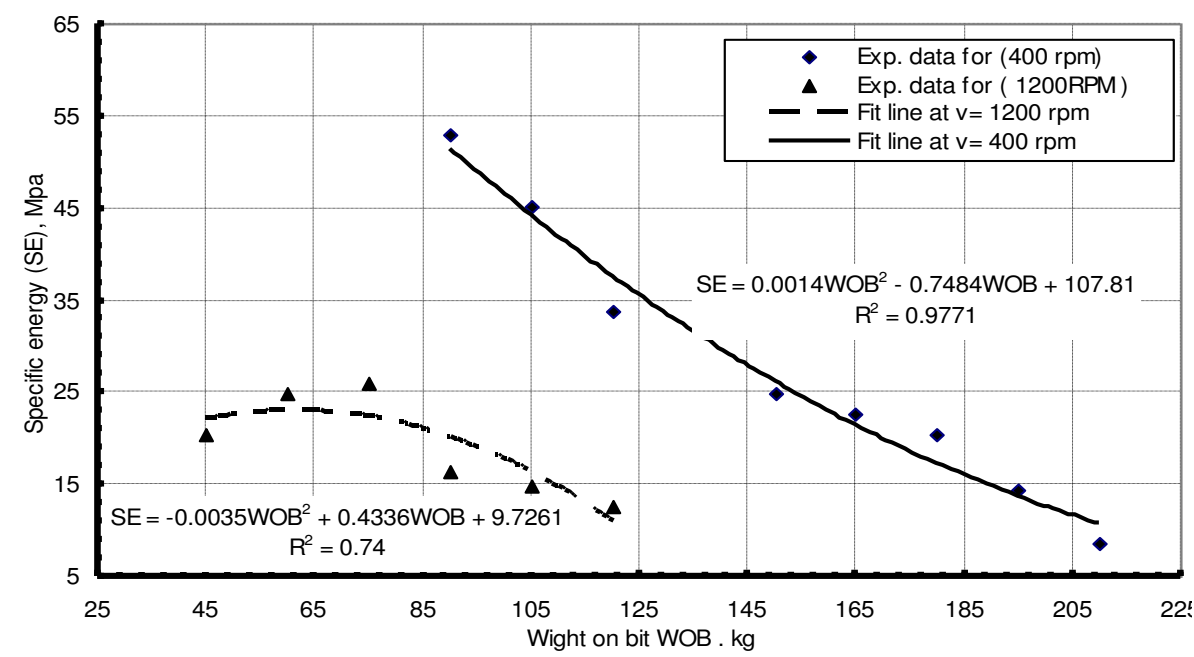

Fig. 15. Relation between (WOB) and (SE) at $400 \mathrm{rpm}$ and $1200 \mathrm{rpm}$ for white Marble rock.

Journal of Engineering Sciences, Assiut University, Faculty of Engineering, Vol. 41, No. 2, March, 2013, E-mail address: jes@aun.edu.eg 
M. M. Elbeblawi et al, Using Diamond Core Bit To Determine The Suitable Operating Parameters In Drilling Some Marble Rocks, pp. 723 - 745

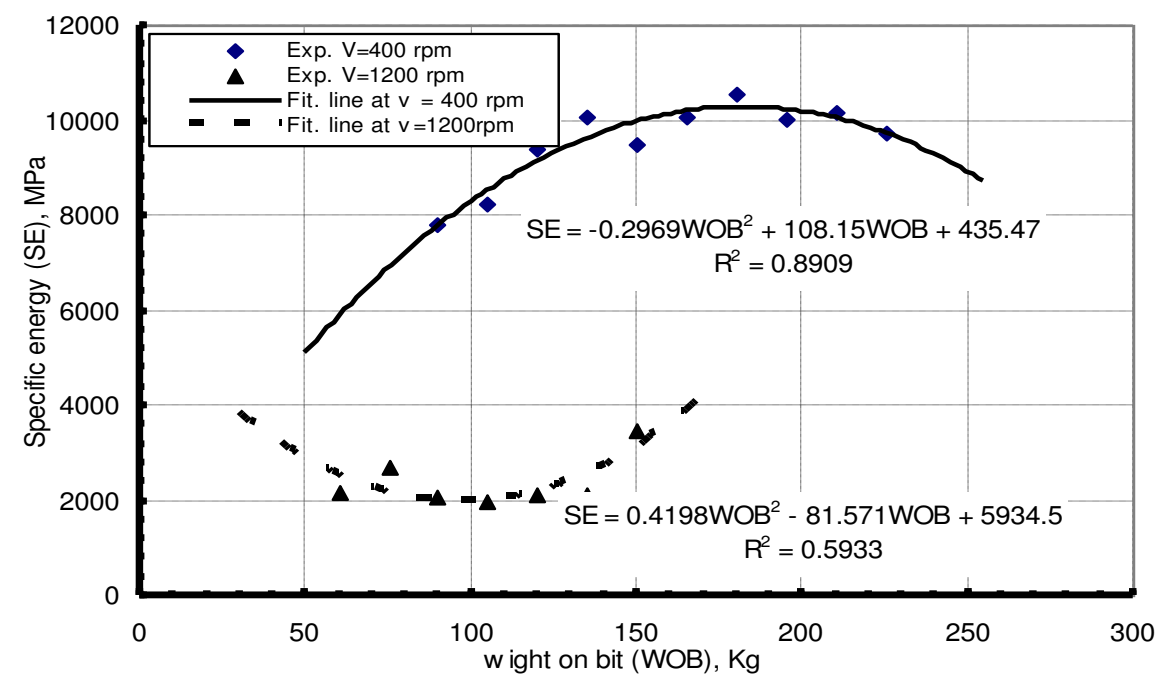

Fig. 16. Relation between (WOB) and (SE) at $400 \mathrm{rpm}$ and $1200 \mathrm{rpm}$ for Sunny Marble rock

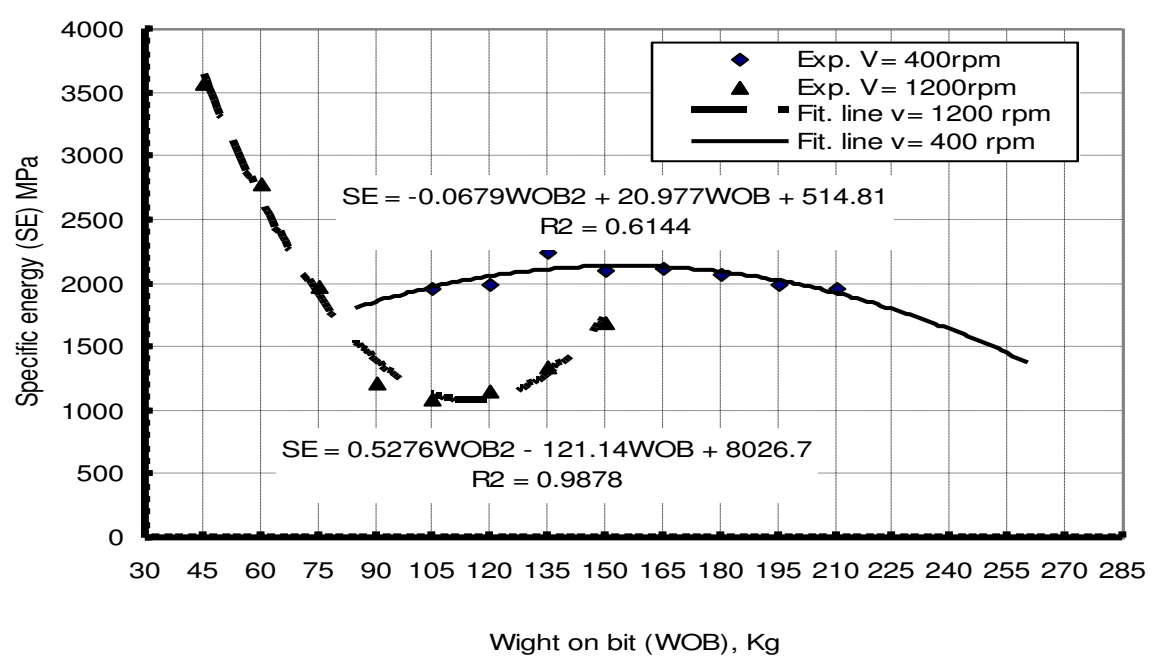

Fig. 17. Relation between (WOB) and (SE) at $400 \mathrm{rpm}$ and $1200 \mathrm{rpm}$ for Yellow Marble rock

Journal of Engineering Sciences, Assiut University, Faculty of Engineering, Vol. 41, No. 2, March, 2013,E-mail address: jes@aun.edu.eg 
M. M. Elbeblawi et al, Using Diamond Core Bit To Determine The Suitable Operating Parameters In Drilling Some Marble Rocks, pp. 723 - 745

\subsection{Relations between PR and SE at low and high speed}

Table (2) gives the different values of the SE and PR in all rocks. Figs. (18), (19) show the relationships between PR and SE in black marble at low and high speed respectively. The SE decreases with the increase in the PR to $1850 \mathrm{MPa}$, and with the increase of PR, $\mathrm{SE}$ increases to $3103 \mathrm{MPa}$ at low speed (400 rpm). For the high speed (1200rpm) SE decreases with an increase in the PR.

Figs. (20), (21) illustrate the relations between PR and SE in white marble at low and high speed respectively. The SE decreases with the increase in the PR, at PR $=1.24$ $\mathrm{mm} / \mathrm{sec}$. SE was at a min. value $300 \mathrm{Mpa}$ and with the increase of PR, SE increases to 500 Mpa at low speed $(400 \mathrm{rpm})$. In the high speed $(1200 \mathrm{rpm})$ SE decreases with the increase in PR.

Figs. (22), (23) illustrate the relations between PR and SE in Sunny marble at low and high speed respectively. At low speed the specific energy (SE) increases with the increase in the PR, till a maximum point of $10350 \mathrm{MPa}$ and then decreases beyond the value of PR $=0.32 \mathrm{~mm} / \mathrm{sec}$. At high rotary speed the specific energy decreases with the increase in the penetration rate till $2040 \mathrm{MPa}$ and then inceases beyond the value of $\mathrm{PR}=0.85 \mathrm{~mm} / \mathrm{sec}$.

Figs. (24), (25) illustrate the relations between PR and SE in yellow marble at low and high speed respectively. In the low speed $(400 \mathrm{rpm}) \mathrm{SE}$ decreases with the increase in the PR. At high rotary speed $(1200 \mathrm{rpm})$ the $\mathrm{SE}$ decreases with the increase in PR, at PR $=1.2$ $\mathrm{mm} / \mathrm{sec}$. SE was at min. value $1200 \mathrm{Mpa}$ and with the increase of PR, SE increase to 1400 Mpa.

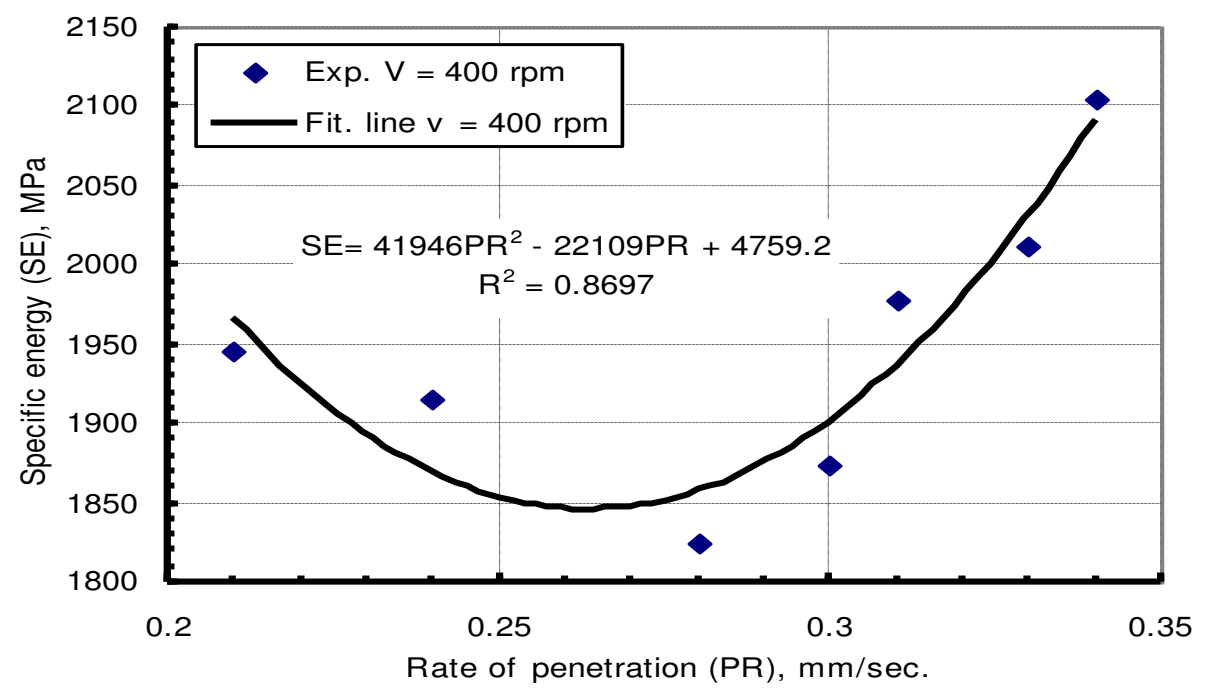

Fig. 18. Relations between penetration rate (PR) and specific energy (SE) in Black Marble at low speed

Journal of Engineering Sciences, Assiut University, Faculty of Engineering, Vol. 41, No. 2, March, 2013, E-mail address: jes@aun.edu.eg 
M. M. Elbeblawi et al, Using Diamond Core Bit To Determine The Suitable Operating Parameters In Drilling Some Marble Rocks, pp. 723 - 745

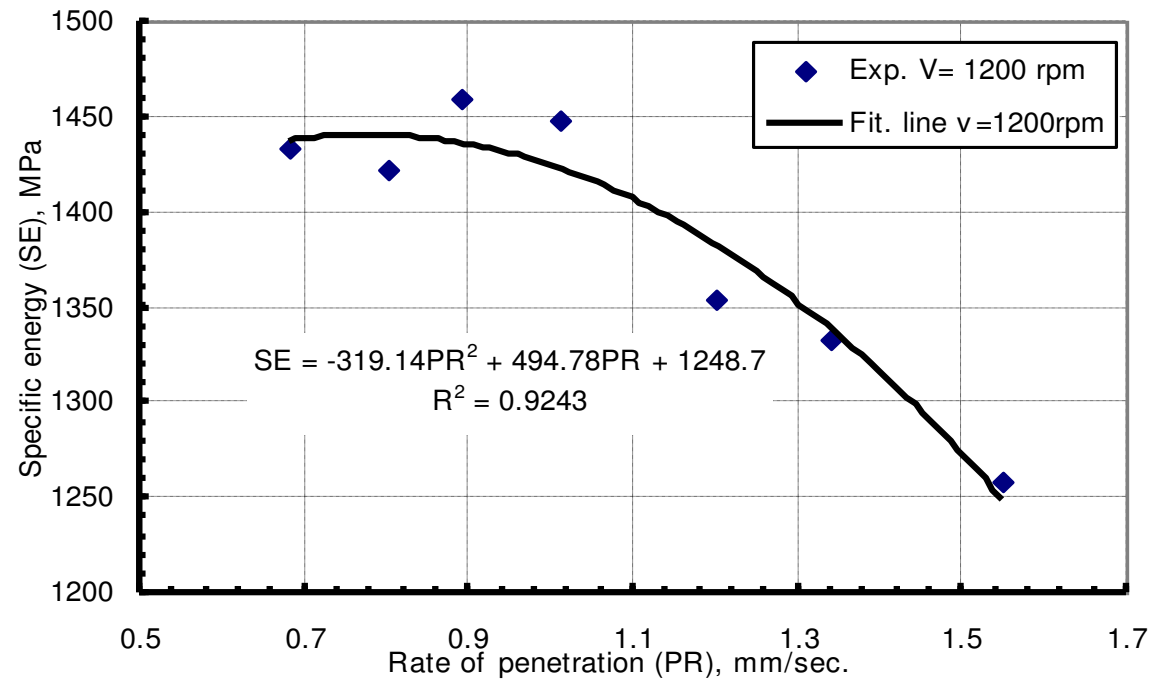

Fig. 19. Relations between penetration rate (PR) and specific energy (SE) in Black Marble at high speed.

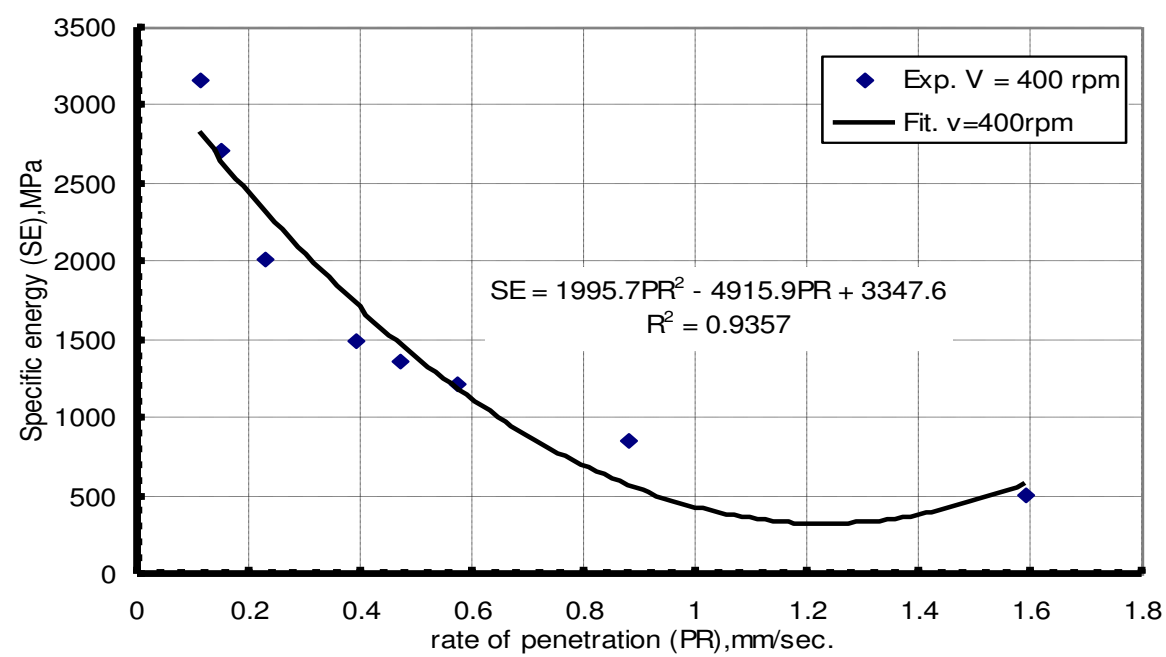

Fig. 20. Relations between penetration rate (PR) and specific energy (SE) in white Marble at low speed

Journal of Engineering Sciences, Assiut University, Faculty of Engineering, Vol. 41, No. 2, March, 2013, E-mail address: jes@aun.edu.eg 
M. M. Elbeblawi et al, Using Diamond Core Bit To Determine The Suitable Operating Parameters In Drilling Some Marble Rocks, pp. 723 - 745

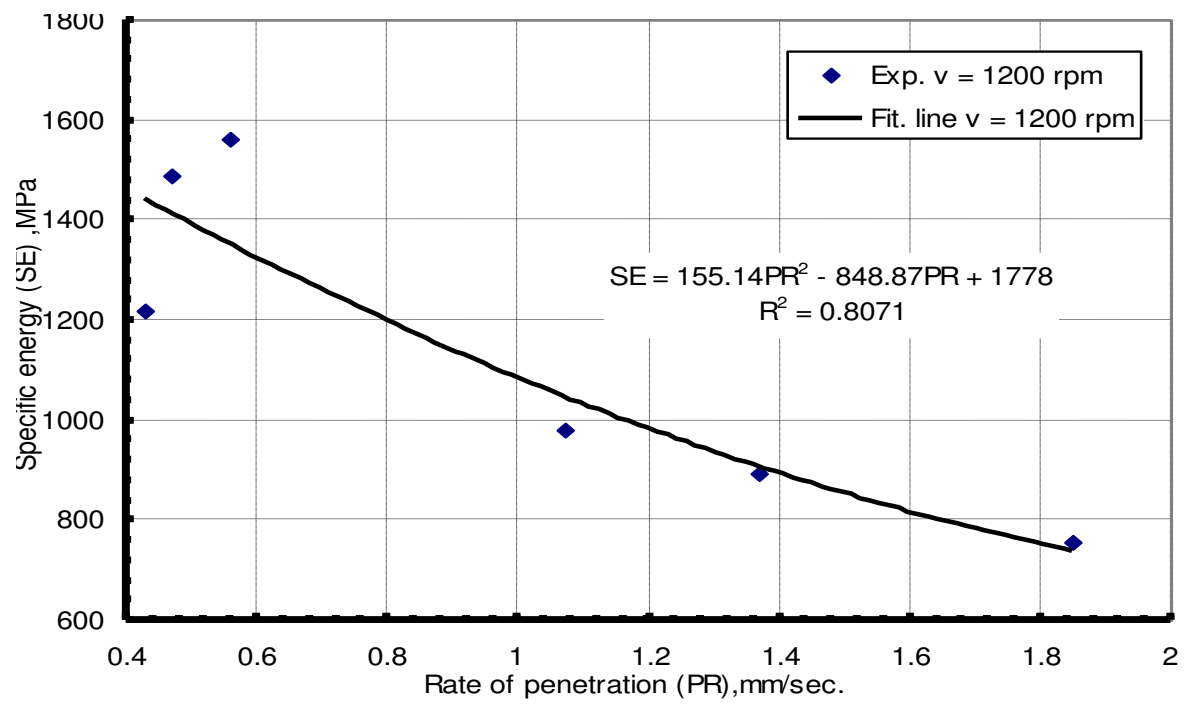

Fig. 21. Relations between penetration rate (PR) and specific energy (SE) in white Marble at high speed

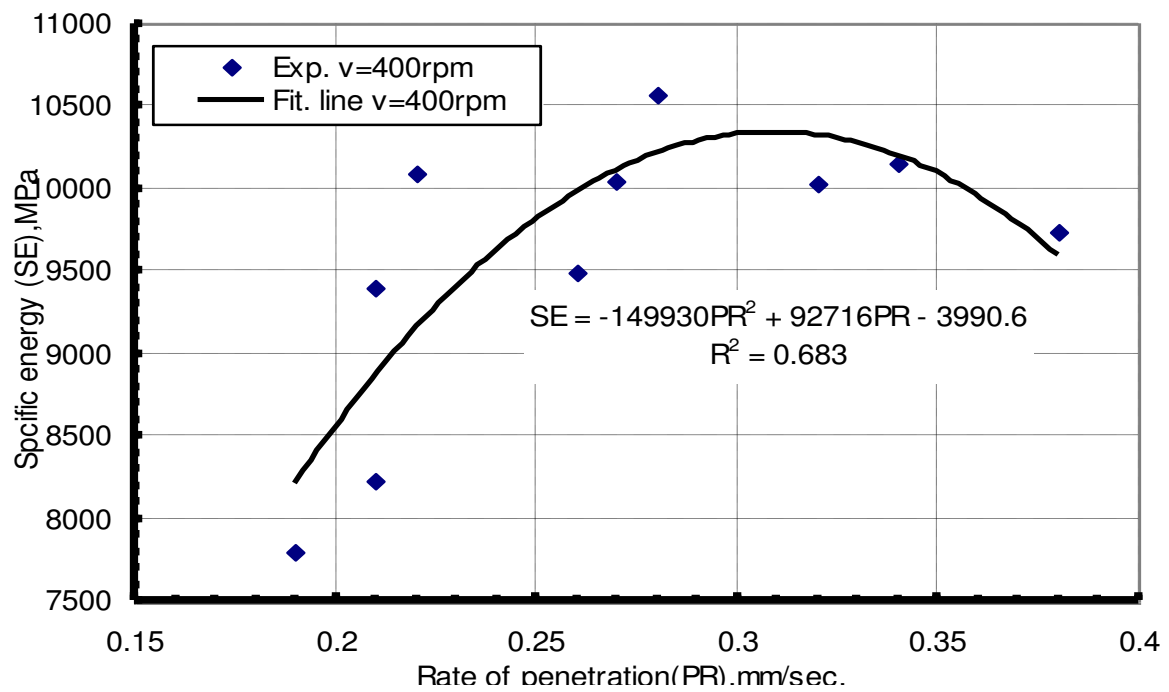

Fig. 22. Relations between penetration rate (PR) and specific energy (SE) in Sunny Marble at low speed

Journal of Engineering Sciences, Assiut University, Faculty of Engineering, Vol. 41, No. 2, March, 2013, E-mail address: jes@aun.edu.eg 
M. M. Elbeblawi et al, Using Diamond Core Bit To Determine The Suitable Operating Parameters In Drilling Some Marble Rocks, pp. 723 - 745

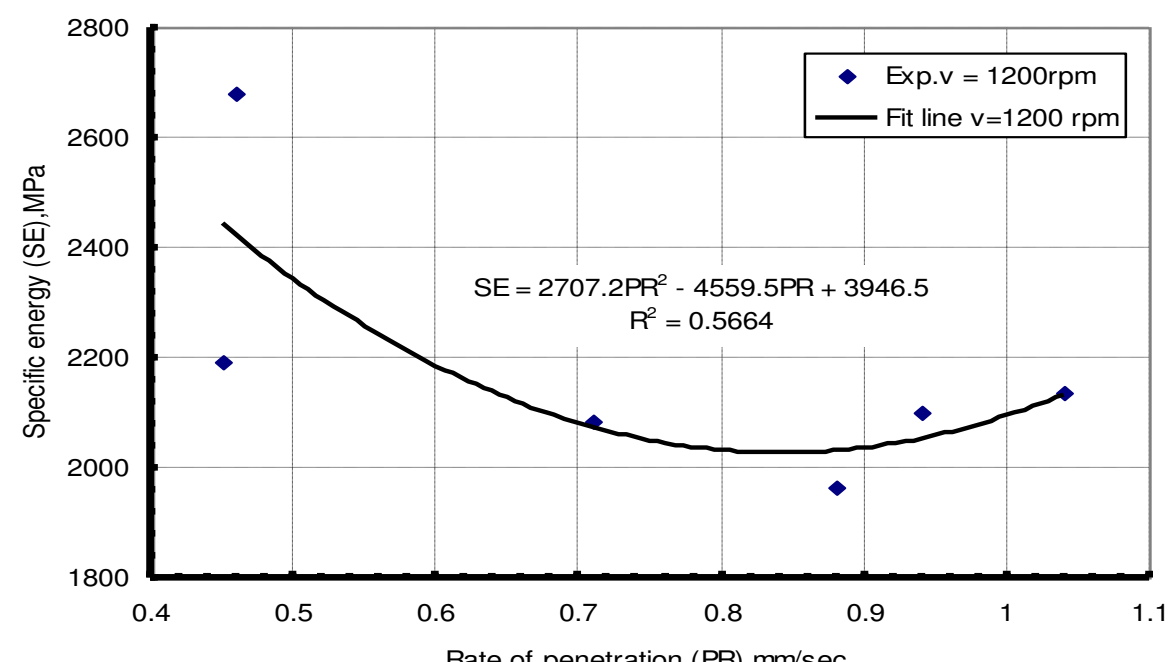

Fig. 23. Relations between penetration rate (PR) and specific energy (SE) in Sunny Marble at high speed

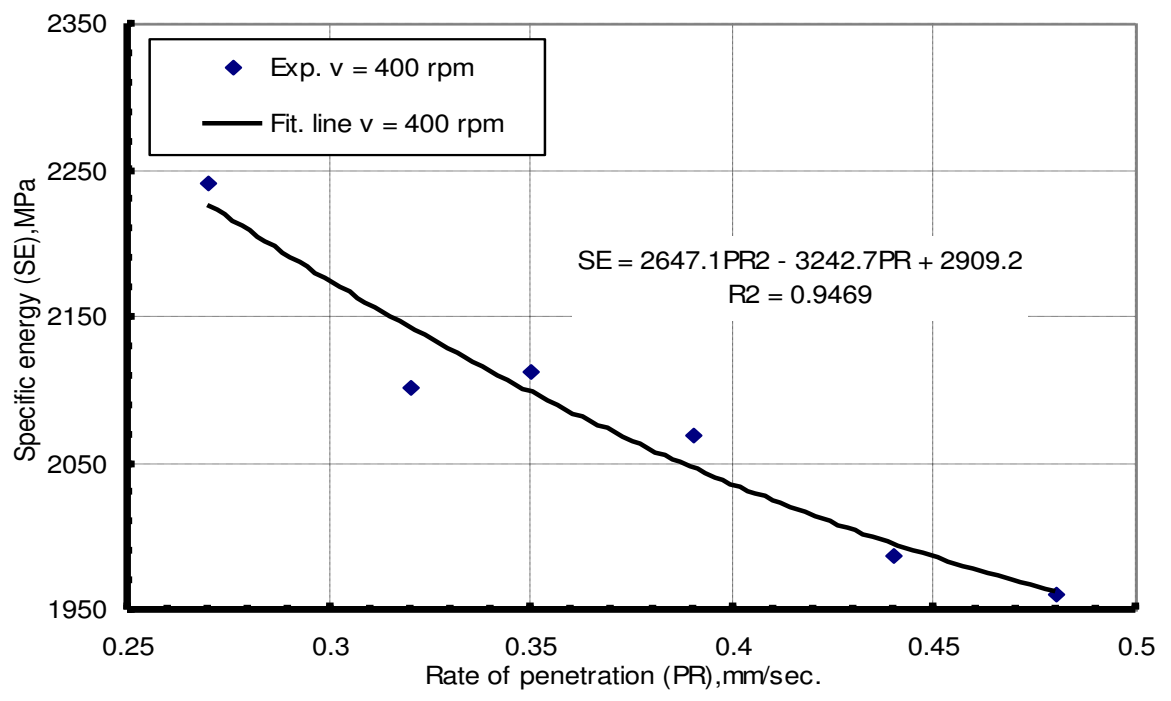

Fig. 24. Relations between penetration rate (PR) and specific energy (SE) in Yellow Marble at low speed

Journal of Engineering Sciences, Assiut University, Faculty of Engineering, Vol. 41, No. 2, March, 2013, E-mail address: jes@aun.edu.eg 
M. M. Elbeblawi et al, Using Diamond Core Bit To Determine The Suitable Operating Parameters In Drilling Some Marble Rocks, pp. $723-745$

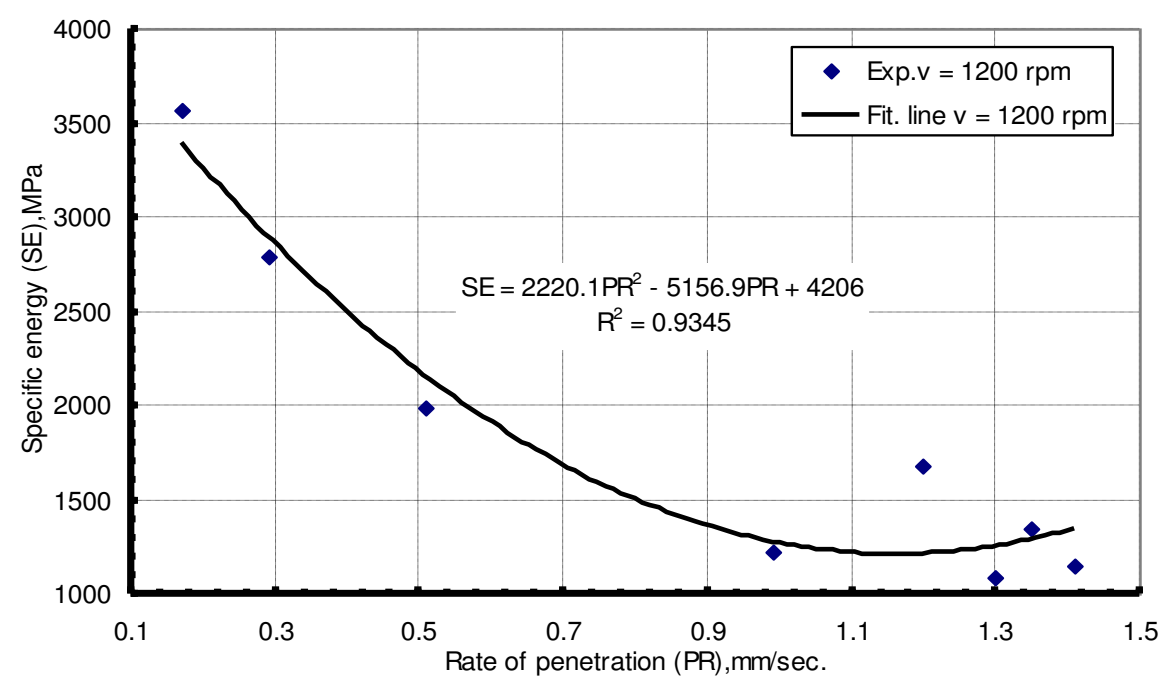

Fig. 25. Relations between penetration rate (PR) and specific energy (SE) in Yellow Marble at low speed

\section{Conclusions and recommendations}

2. Drilling tests were carried out on four marble rocks by using a fixed laboratory diamond core drilling machine with both for low speed at $400 \mathrm{rpm}$ and high speed at

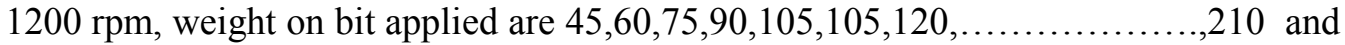
$225 \mathrm{~kg}$.

3. Relations between WOB and both PR, T, and SE where given. Also relation between $\mathrm{PR}$ and SE were given. From the experimental data drilling performance is dependant on operating parameters especially rotary speed and WOB. Mathematical Equations between parameters are given from trend line in curves.

4. In low speed increasing WOB causes an increase in PR. In black marble rock at a maximum of WOB $210 \mathrm{~kg}$ PR was about 1.6 times that of at minimum WOB of 120 $\mathrm{kg}$. PR increases in rocks (White marble), (Sunny marble) and (Yellow marble) at WOB 210,225 and $210 \mathrm{~kg}$ was about 14.5, 2 and 2.8 times that at 90,90 and $75 \mathrm{~kg}$ respectively for the low speed.

5. Penetration rate at high speed is more than that at low speed in a specific load. At WOB of $120 \mathrm{~kg}$ as an example PR at high speed were about 4.2, 8.04, 4.48 and 5.22 times that PR at low speed in rocks (Black marble), (White marble), (Sunny marble) and (Yellow marble) respectively.

6. Specific energy value varies according to the type of rock and weight; the best values of SE which give best values of PR were 512 and $1961 \mathrm{Mpa}$ at WOB of $210 \mathrm{Kg}$ in rocks white and yellow marble at $400 \mathrm{rpm}$ respectively. The best values of SE which

Journal of Engineering Sciences, Assiut University, Faculty of Engineering, Vol. 41, No. 2, March, 2013, E-mail address: jes@aun.edu.eg 
M. M. Elbeblawi et al, Using Diamond Core Bit To Determine The Suitable Operating Parameters In Drilling Some Marble Rocks, pp. 723 - 745

give reasonable values of PR were $1824 \mathrm{Mpa}$ and $7789 \mathrm{Mpa}$ at WOB of 150 and 90 $\mathrm{Kg}$ in black and Sunny marble at $400 \mathrm{rpm}$ respectively.

7. The best values of SE which give best values of PR were 1257and $756 \mathrm{Mpa}$ at WOB 180 and $120 \mathrm{Kg}$ in black and white marble rocks at $1200 \mathrm{rpm}$ respectively. The best values of SE which give reasonable values of PR were $1962 \mathrm{Mpa}$ and $1088 \mathrm{Mpa}$ at WOB of $105 \mathrm{Kg}$ in Sunny and yellow marble at $1200 \mathrm{rpm}$ respectively.

8. We recommend to use the high rotary speed for drilling in the quarry marble, because the high rotary speed gives high penetration rate and low energy consumption.

\section{Refrances}

[1] Serhat Akin, and Celal Karpuz " Estimating drilling parameters for diamond bit drilling operations using artificial neural networks" Int. J. Geomech. 8, 68 ,2008

[2] Mostafa M. Elbeblawi, Mohamed A. Sayed, Gamal Y. Boghdadi and Helal H. Hamd_Allh" Effect of operating parameters and formation properties on penetration rate in some sandstone rocks by using diamond core bit". Journal of Engineering Sciences, Assiut unv. , vol. 40 No.2 , pp 581- 594, March 2012, Egypt.

[3] p://www.airdrill.com.au/pdf/The-Drilling-Industry-General/diamond-core-drilling.pdf

[4] N. Bilgin , S. Kahraman "Drillability prediction in rotary blast hole drilling" 1a" International Mining Congress and Exhibition ot Turkey-IMCET 2003, \# 2003, ISBN 975-395-605-3

[5] University of a Arizona Mining and Geological Engineering - Rock Excavation Course Notes - Spring 2003http://www.lonestarbit.com/mining/415n.pdf

[6] Gamal Y. Boghdady "Mechanical and geological influences on drilling limestone rock at low rotary speed" Journal of Engineering Sciences , Assiut University, Vol. 38 , No. 1,pp.259-270 , January 2010.

[7] Yusuf Babatunde, Stephen Butt, John Molgaard, Farid Arvani."Investigation of the effects of vibration frequency on rotary drilling penetration rate using diamond drag bit" 45th US Rock Mechanics / Geomechanics Symposium held in San Francisco, CA, June 26-29, 2011.

[8] N. Bilgin, S. Kahraman "Drillability prediction in rotary blast hole drilling" 1a" International Mining Congress and Exhibition ot Turkey-IMCET 2003, \# 2003, ISBN 975-395-605-3

[9] B. Celada1, J. M. Galera2, C. Muñoz3, I. Tardáguila3 "The use of the specific drilling energy for rock mass characterisatin and tbm driving during tunnel construction" p://www.geocontrol.es/lista/listado/vdocumento.asp?f=use $\% 20$ of $\% 20$ specific $\% 20$ drilling_cela da.pdf

[10] Mohamed A. Sayed and Abdel Nasser M. Abdel Rahman " Using diamond core drilling parameters for identifying the rock type to be drilled" Journal of Engineering Sciences , Assiut University, Vol. 30 , No.4,pp.1011-1025, October 2002.

[11] http://www.egyptmarbles.com/industry-info/

[12] "The Geology of Egypt: An Annotated Bibliography" Farouk El-Baz

http://www.googlebookes.es/lista/listado/vdocumento.asp?f=use \%20of\%20specific\%20drilling_c elada.pdf

[13] http://ibm.nic.in/imyb2010_marble.pdf

[14] Mohammed Fasheloum "Investigation of drilling parameters indictors" Thesis submitted to the University of Nottingham for the degree of Doctor of Philosophy, April 1997

[15 http://www.fanarco.net/books/Drilling_Engineering_Workbook_-_Baker_Hughes_INTEQ.pdf

[16] Celada, B. Galera, J. M. Muñoz, C. Tardáguila,I. "The use of the specific drilling energy for rock mass characterization and TBM driving during tunnel construction"

Journal of Engineering Sciences, Assiut University, Faculty of Engineering, Vol. 41, No. 2, March, 2013, E-mail address: jes@aun.edu.eg 
M. M. Elbeblawi et al, Using Diamond Core Bit To Determine The Suitable Operating Parameters In Drilling Some Marble Rocks, pp. 723 - 745

http://www.geocontrol.es/lista/listado/vdocumento.asp?f=use\%20of\%20specific\%20drilling_celad a.pdf

[17] B. Rashidi "Real-Time Drill Bit Wear Prediction by Combining Rock Energy and Drilling Strength Concepts"

http://dc337.4shared.com/download/07ivPLGr/RealTimeDrillBitWearPredictionbyCombiningRoc kEnergyandDrillingStrength Concepts

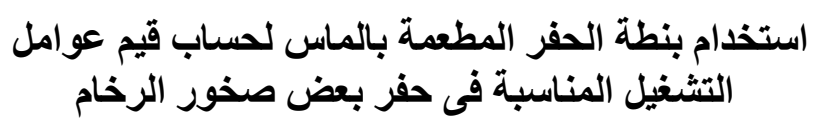

ملخص:

فىى هذه الدر اسة تم الحفر فى اربعة انواع من صخور الرخام بإستخدام ماكينة حفرمعملية ثابتة بإستخدام

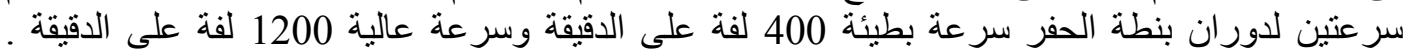

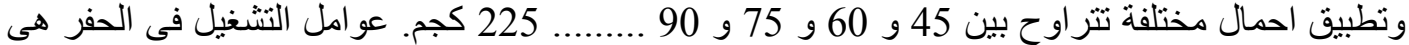

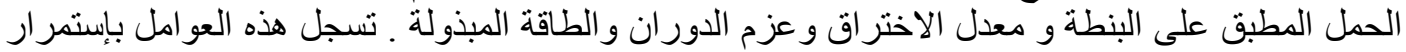

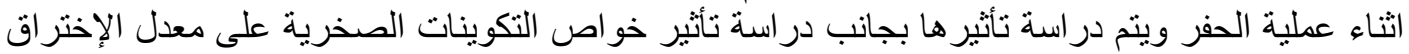

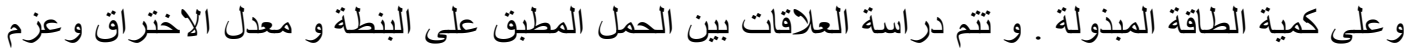

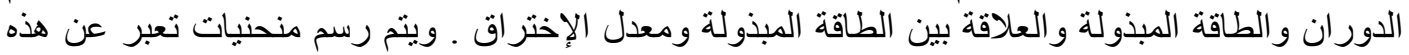

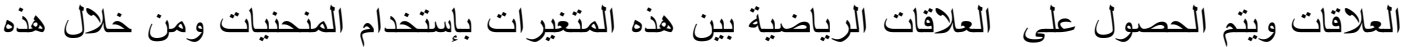

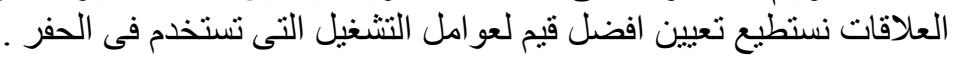

Journal of Engineering Sciences, Assiut University, Faculty of Engineering, Vol. 41, No. 2, March, 2013, E-mail address: jes@aun.edu.eg 